\title{
Activation of human lymphomononuclear cells by peptides derived from extracellular matrix proteins
}

\author{
Natalia López-Moratalla a, María del Mar Calonge a , María J. López-Zabalza a , \\ L. Alberto Pérez-Mediavilla a , María L. Subirá ${ }^{b}$, Esteban Santiago ${ }^{\text {a,* }}$ \\ a Department of Biochemistry, University of Navarra, Apartado 273, 31080 Pamplona, Spain \\ ${ }^{\mathrm{b}}$ Department of Immunology, University of Navarra, Pamplona, Spain
}

Received 25 May 1994; revised 31 August 1994; accepted 30 September 1994

\begin{abstract}
A series of peptides of 15 amino acids with sequences contained in human extracellular matrix (ECM) proteins (fibronectin, laminin A, laminin B1, tenascin, undulin, $\alpha_{1}$-chain of type IV and VIII collagen and $\alpha_{2}$-chain of type VIII collagen) have been synthesized. The selected structures conformed to the following pattern: (i) Pro at position 6, (ii) Leu, Lys, Ile, Val, Ala or Gly at position 2, (iii) Glu or Asp at position 11. Fibronectin and the indicated peptides, when present in cultures of lymphomononuclear cells from healthy donors, promoted stimulation of monocytes manifested by a release of IL-1 $\alpha, \mathrm{IL}-1 \beta, \mathrm{IL}-6$ and INF $\alpha$; an increase in the percentage of cells expressing CD14, CD16, CD11b and CD14/CD16; an increase in cytotoxicity against HT-29. Cytotoxicity against K562 and Daudi cells (targets of NK and LAK cells) was also observed together with an increase in the percentage of cells expressing CD56, CD56/CD16 (corresponding to NK cells), and CD56/CD8 (corresponding to NK-like lymphocytes), indicating a stimulation of lymphocytes. Activated monocytes and lymphocytes contained a large number of granules with DNAse activity. These results suggest that at least some of the immunological properties of ECM proteins could be accounted for by motifs fulfilling a characteristic sequence pattern shared by all of them.
\end{abstract}

Keywords: Extracellular matrix protein; $\mathrm{CD} 14^{+} / \mathrm{CD} 16^{+}$Monocyte; CD56 surface marker; LAK dependent cytotoxicity; TNF $\alpha$; Interleukin release; (Human)

\section{Introduction}

Extracellular matrix (ECM) proteins are known to play an active role in the physiology of the tissues they belong to. They also affect the activity of cells penetrating the tissues as a consequence of migratory processes. An increasing number of reports underscore the involvement of ECM proteins in a variety of processes related to the activity of the immune system, such as activation, proliferation, differentiation, homing and cell migration [1-3]. Fibronectin as well as fragments derived from it through digestion with chymotrypsin are known to stimulate the secretion of TNF $\alpha$ [4].

\footnotetext{
Abbreviations: ECM, extracellular matrix; Fn, fibronectin; LPS, lipopolysaccharide.

* Corresponding author. Fax: +34 48105649.
}

The immunomodulating properties exhibited by peptides derived from Staphylococcus aureus protein A allowed us to identify a common structural pattern associated with them: a length of at least 15 amino acid residues with a proline at position 6; valine, leucine, isoleucine, glycine, alanine or lysine at position 2; and glutamic or aspartic acid at position 11 [5]. Surprisingly, this pattern is present in a number of ECM proteins [6-13]. This coincidence prompted us to explore the immunomodulating properties of synthetic peptides modelled after sequences of ECM proteins and containing those structural features. The results show that all these peptides stimulated human lymphomononuclear cells as manifested by: (i) a release of IL-1 $\alpha$, IL-1 $\beta$, IL-6 and TNF $\alpha$; (ii) an increase in the percentage of cells expressing CD14, CD16, CD11b, CD56, CD14/CD16, CD56/CD16 and CD56/CD8; (iii) an increase in cytotoxicity against HT-29, K562 and Daudi cells; and (iv) an increase in granules containing DNAse activity. The possibility that proteolytic fragments from 
ECM proteins might participate as immunomodulators in the process of activation and maturation of monocytes and stimulation of lymphocytes is suggested.

\section{Materials and methods}

\subsection{Cell source and preparations}

Lymphomononuclear cells were isolated (from venous blood drawn from healthy donors) by centrifugation over Ficoll-Hypaque at $2500 \times g$ for $15 \mathrm{~min}$ [4]. Isolation and purification of monocytes was also carried out as described [4], allowing them to adhere for $6 \mathrm{~h}$ at $37^{\circ} \mathrm{C}$ to culture plates and removing nonadherent cells contained in the supernatant followed by three vigorous washings with saline solution. When indicated, the stimulated cells were separated in the following way: after incubating the whole lymphomononuclear population, monocytes were carefully scraped off from the surface of the culture flasks and the resulting cell suspension was treated with magnetizable polystyrene beads coated with a primary monoclonal antibody specific for the CD14 membrane antigen (Dynabeads for monocyte separation, Dynal, Oslo, Norway).

\subsection{Cell culture conditions}

Blood lymphomononuclear cells or monocytes were cultured at $2 \cdot 10^{6}$ per $\mathrm{ml}$ in RPMI-1640 medium (Biochrom, Berlin, Germany) supplemented with $2.5 \%$ of autologous serum, $2 \mathrm{mM}$ L-glutamine, penicillin $(100 \mathrm{U} / \mathrm{ml})$, and streptomycin $(100 \mu \mathrm{g} / \mathrm{ml})$ in humidified atmosphere with $5 \% \mathrm{CO}_{2}$ at $37^{\circ} \mathrm{C}$.

\subsection{Chemical synthesis of peptides}

The synthesis of the various peptides was carried out by the solid phase method of Merrifield [14], with the Fmoc modification [15].

\subsection{Surface markers}

Immunofluorescence studies were performed with a Coulter Epics flow cytometer (Coulter Electronics, Hialeah, FL). The monoclonal antibodies used in this study were: Leu-11a (CD16), Leu-M3 (CD14), Leu-19 (CD56), Leu-2a (CD8), obtained from Becton-Dickinson (Mountain View, CA) and anti-MAC1 (CD11b) from Immunotech (Marseille, France). Antibodies were used as conjugates of fluorescein isothiocyanate (FITC) or Rhodamine 6 G. Each assay was accompanied with its appropriate isotype control. Aliquots containing $5 \cdot 10^{5}$ cells were incubated at $4^{\circ} \mathrm{C}$ in $50 \mu 1$ of PBS- $0.1 \%$ BSA with the monoclonal antibody for $30 \mathrm{~min}$. After incubation the cells were washed twice with cold PBS $/ 0.1 \%$ BSA. Cells were then fixed in $500 \mu \mathrm{l}$ of formaldehyde in $2 \%$ PBS. Forward angle and $90^{\circ}$ light scattering measurements were recorded. 5000 cells were analyzed for each determination. Percentage of positive cells was determined after subtraction of nonspecific labelling events, which, in turn, was calculated in each measurement with the corresponding isotype control.

\subsection{Cytokine determinations}

IL- $1 \alpha$, IL- $1 \beta$, IL- 6 and TNF $\alpha$ were measured by the quantitative 'sandwich' enzyme immunoassay technique with commercially available kits (Quantikine, $R$ and D Systems).

\subsection{Cytotoxicity assay}

The $4 \mathrm{~h}{ }^{51} \mathrm{Cr}$ release cytolysis assay [16] was performed with K562 and Daudi cells as targets, essentially as previously described [5]. Cytotoxicity associated with monocytes was determined using lymphomononuclear cells or purified monocytes as effector cells, and HT-29 cells from a human adenocarcinoma [17] cultured in monolayer as target cells. HT-29 cells were labelled with $1 \mu \mathrm{Ci} / \mathrm{ml}$ of $\left[{ }^{3} \mathrm{H}\right]$ thymidine when they had reached a confluence of $50 \%$ and incubated at $37^{\circ} \mathrm{C}$ for $16-18 \mathrm{~h}$. The incubation with the effector cell was carried out at $37^{\circ} \mathrm{C}$ and $5 \% \mathrm{CO}_{2}$ for $72 \mathrm{~h}$.

\subsection{Extraction of granule proteins and gel electrophoresis}

The isolation of secretion granules was carried out using a Percoll density-gradient after disrupting the cells with a nitrogen bomb [18]. Granule proteins were extracted following the procedure used by Podack et al. [19] as a preliminary step in the purification of perforin 1 from cytolytic T-cell granules. Isolated granules were mixed with an equal volume of $1 \mathrm{M} \mathrm{NaKHPO}_{4}$ buffer (pH 7.4), containing $10 \mathrm{mM}$ benzamidine-HCl, $1 \mathrm{mM}$ EDTA and 3 $\mathrm{mM} \mathrm{NaN}{ }_{3}$. After the addition of a small volume of a concentrated solution of phenylmethylsulfonyl fluoride in methanol to give a final concentration of $2 \mathrm{mM}$, the mixture was allowed to stand on ice for $30 \mathrm{~min}$. The white precipitate of Percoll was removed by centrifugation at $30000 \times g$ for $30 \mathrm{~min}$; the supernatant was dialyzed against $10 \mathrm{mM} \mathrm{NaKHPO}{ }_{4}$ buffer (pH 7.4), $1 \mathrm{mM}$ EDTA and 3 $\mathrm{mM} \mathrm{NaN}_{3}$. Protein electrophoresis was carried out following the technique of Laemmli and Favre [20]. The protein mixture 'Dalton Mark III L' (Sigma, Saint Louis, MO) was used as reference for the estimation of molecular mass.

\subsection{Detection of DNAse activity}

The detection of DNAse activity in the protein extract was carried out by its ability to degrade genomic DNA. Approx. $50 \mu \mathrm{g}$ of the extracted granule proteins were 
incubated with $10 \mu \mathrm{g}$ of protein-free DNA at $37^{\circ} \mathrm{C}$ for 24 $\mathrm{h}$ in $100 \mu \mathrm{l}$ of a $50 \mathrm{mM} \mathrm{NaCl}, 10 \mathrm{mM} \mathrm{MgCl}, 1 \mathrm{mM}$ dithiothreitol, $10 \mathrm{mM}$ Tris $\mathrm{HCl}$-buffer (pH 7.9). An aliquot of $50 \mu \mathrm{l}$ of the resulting mixture was applied to a $1 \%$ agarose gel, and subjected to electrophoresis at a voltage of $70 \mathrm{~V}$ in $1 \mathrm{mM}$ EDTA, $40 \mathrm{mM}$ Tris-HCl buffer (pH 7.5), containing $0.5 \mu \mathrm{g}$ per $\mathrm{ml}$ of ethidium bromide. Genomic DNA was obtained from human blood as described in the literature [21].

\section{Results and discussion}

\subsection{Sequences of active peptides}

The amino acid sequence of different proteins from extracellular matrix is already well known [6-13]. Peptides fulfilling the structural requirements described as needed for immunomodulating activity [5] and consisting of 15 amino acids (14 of them encompassing sequences present in fibronectin [6], laminin A [7], laminin B1 [8], $\alpha_{1}$-chain of type IV collagen [9], tenascin [10], undulin [11], $\alpha_{1}$-chain of type VIII collagen [12] and $\alpha_{2}$-chain of type VIII collagen [13]) were synthesized. The extra amino acid residue, always on the carboxyl end, was valine, added for synthesis convenience. Table 1 shows the sequence of synthetic peptides capable of inducing cytotoxicity against tumour cell lines HT-29, K562 or Daudi, when lymphomononuclear cells were incubated in the presence of any of them, for 7 days. Table 2 shows the cytotoxicity against HT-29 cells induced by Fn or peptides derived from this or other ECM proteins on lymphomononuclear cells or purified monocytes. Peptide NVLGAPKKLNESQAV ( $\mathrm{Pa}$ ) and IFN $\gamma$ were used as positive controls, and peptide ADAQQNKFNKDQQS $(\mathrm{Pc})$ as negative control [5]. A maximum value for the cytotoxicity induced on isolated monocytes was observed at a 2:1 effector to target cell ratio, whereas cytotoxicity induced on lymphomononuclear cells increased with an increase of the effector to target cell ratio (from 2:1 to 20:1). A potent enhancement of both monocyte and macrophage tumour cell cytotoxicity elicited by $\mathrm{Fn}$ has already been reported [22]. Fig. 1 shows the dose-dependent cytotoxicity against K562 and Daudi cells induced by Fn or peptides derived from ECM proteins. $\mathrm{Pa}$ was used as positive control, and Pc as negative control. A maximum value of cytotoxicity
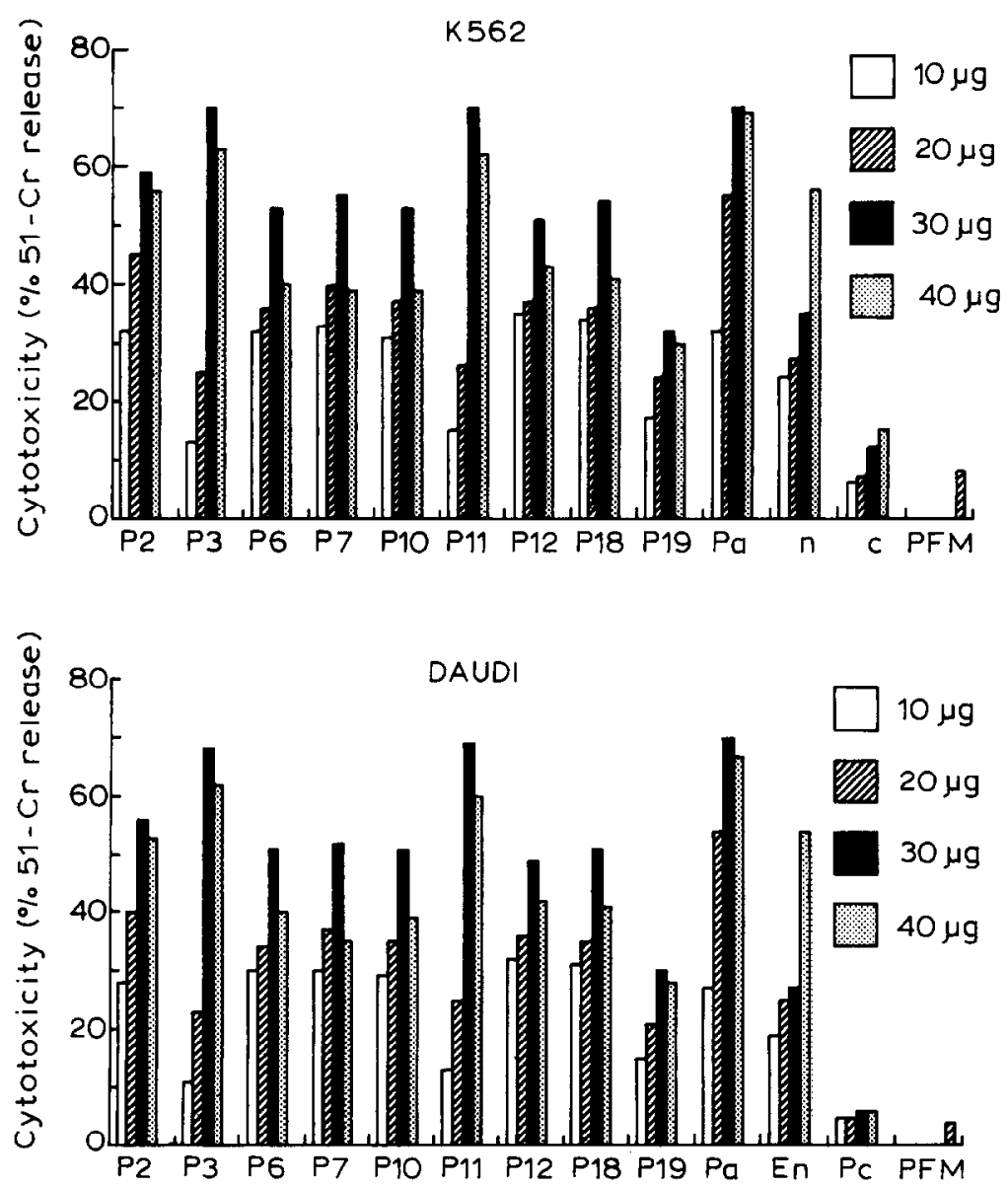

Fig. 1. Cytotoxicity induced by synthetic peptides derived from EMC proteins on lymphomononuclear cells. Cytotoxicity was determined after 7 days of incubation. Results are expressed as percentage of ${ }^{51} \mathrm{Cr}$ release using K562 (top) or Daudi (bottom) cells as target. Effector to target ratio was 50:1. The results are representative of cells obtained from 10 different healthy donors. See Table 1 for peptide identification. PFM, peptide-free medium. 
induced by any of the active peptides included in Table 1 was reached with $30 \mu \mathrm{g}$ per $\mathrm{ml}$. In the case of Fn the cytotoxicity was higher at 40 than at $30 \mu \mathrm{g}$, a result consistent with the much higher molecular mass of Fn. The cytotoxicity induced by active peptides was also found to be time-dependent when measured in the interval from 1 to 7 days; after a slow increase in the first 3 days of incubation a sharp increase in cytotoxicity was observed between days 3 and 5 to level off between days 5 and 7 (data not shown).

\subsection{Surface markers of lymphomononuclear cells after incubation in the presence of active peptides,}

Surface markers in the cell populations after incubation in the presence of active peptides or fibronectin were also studied. Table 3 shows the results obtained together with those corresponding to peptide $\mathrm{Pa}$ and $\mathrm{Pc}$ used as positive and negative controls respectively. The proportion of cells expressing markers CD11b (NK, monocytes and activated macrophages), CD14 (monocytes and macrophages), CD16 (macrophages, monocytes and NK), and CD56 (NK and activated lymphocytes) was elevated in cell populations incubated in the presence of active peptides or fibronectin with respect to those incubated in the absence of peptides or incubated in the presence of negative control Pc. The percentage of cells expressing these markers remained unaltered in populations incubated in the absence of peptides or in the presence of Pc. The induction of these markers caused by any of the active peptides was found to

\section{Table 1}

Sequences of synthetic peptides, derived from extracellular matrix proteins, active as inducers of cytotoxicity on human lymphomononuclear cells

\begin{tabular}{lllc}
\hline Product tested & Peptide sequence & & \\
a & Protein & Position \\
\hline P1 & KLGVRPSQGGEAPR & Fibronectin & $1088-1101$ \\
P2 & IKGLKPGVVYEGQL & Fibronectin & $639-652$ \\
P3 & IISCHPVGTDEEPL & Fibronectin & $2015-2028$ \\
P4 & QIGHIPREDVDYHL & Fibronectin & $1967-1980$ \\
P5 & LVRYSPVKNEEDVA & Fibronectin & $1271-1284$ \\
P6 & LKERNPEGCSECFC & Laminin A & $475-488$ \\
P7 & VVRLVPENFRDFNT & Laminin A & $620-634$ \\
P8 & MLRESPGGMREKGR & Laminin A & $1981-1993$ \\
P9 & TKVSHPALLSDGKW & Laminin A & $2770-2783$ \\
P10 & GISTGPMKKVDDII & Laminin B1 & $155-168$ \\
P11 & QALASPGSCLDEFR & $\alpha_{1}$ Collagen IV & $1569-1582$ \\
P12 & IGNLKPDTEYEVSL & Tenascin & $430-443$ \\
P13 & RIKYAPISGGDHAE & Tenascin & $494-507$ \\
P14 & LLWKTPLAKFDRYR & Tenascin & $573-586$ \\
P15 & QGYRTPVLSAEAST & Tenascin & $719-732$ \\
P16 & RGYRTPVLSAEAST & Tenascin & $992-1005$ \\
P17 & RVTWHPLSADEGLH & Undulin & $454-467$ \\
P18 & GKEAVPKKGKEIPL & $\alpha_{1}$ Collagen VIII & $100-113$ \\
P19 & AGLHLPNGGVEGAV & $\alpha_{2}$ Collagen VIII & $484-497$ \\
\hline
\end{tabular}

\footnotetext{
${ }^{a}$ An extra valine residue, not shown, was added in the C-terminus for synthesis convenience.

${ }^{b}$ Numbering of the amino acid residues at the corresponding protein.
}

Table 2

Cytotoxicity induced by synthetic peptides derived from ECM proteins on lymphomononuclear cells or monocytes against HT-29 cells

\begin{tabular}{lll}
\hline Product tested & Monocyte & $\begin{array}{l}\text { Lymphomononuclear } \\
\text { cells }\end{array}$ \\
\hline None & 26 & 27 \\
Pc & 26 & 28 \\
Pa & 60 & 67 \\
Fn & 50 & 51 \\
P1 & 51 & 57 \\
P2 & 56 & 63 \\
P3 & 70 & 67 \\
P4 & 62 & 62 \\
P5 & 62 & 63 \\
P6 & 51 & 62 \\
P7 & 53 & 60 \\
P8 & 46 & 51 \\
P9 & 44 & 48 \\
P10 & 54 & 62 \\
P11 & 68 & 68 \\
P12 & 56 & 64 \\
P13 & 61 & 60 \\
P14 & 42 & 45 \\
P15 & 41 & 43 \\
P16 & 47 & 59 \\
P17 & 56 & 60 \\
P18 & 52 & 60 \\
P19 & 50 & 53 \\
IFN $\gamma$ & 73 & 70 \\
\hline Pe & 59
\end{tabular}

Peptide concentration was $30 \mu \mathrm{g} / 10^{6}$ cells and that of Fn $40 \mu \mathrm{g} / 10^{6}$ cells. IFN $\gamma$, at a concentration of $100 \mathrm{U} / 10^{6}$ cells, was used as reference control. Cytotoxicity was determined after 7 days of incubation and expressed as \% of $\left[{ }^{3} \mathrm{H}\right]$ thymidine released. Results are representative of cells obtained from five different donors and correspond to the mean of the values of two replicate wells. Standard deviations were $<10 \%$. Effector to target cell ratio was 2:1 when using isolated monocytes and 20:1 with the whole population of lymphomononuclear cells.

be time-dependent (data not shown): the percentage of cells expressing CD14 and CD16 reached values close to its maximum after the second day of incubation; however, in the case of CD11b and CD56 no change in the percentage of cells expressing them was observed until past $48 \mathrm{~h}$. The existence of a subset of monocytes coexpressing CD14 and CD16 antigens (10-15\% of all monocytes), differing in some features from monocytes with a high expression of CD14 $[23,24]$, prompted us to explore the possibility that this precise group could be affected by the active peptides. In a different set of experiments the percentage of cells expressing both CD14 and CD16 surface markers has been determined after incubating lymphomononuclear cells in the presence of active peptides or Fn for 7 days. The proportion of cells expressing both markers was double in the case of Fn, triple in the case of P6 and quadruple in the presence of either P3 or P11, with respect to cells incubated in the absence of peptides. No change in that proportion was observed when the incubation was carried out in the presence of Pc or IL-2 (500 U per $10^{6}$ cells). 
Table 3

Phenotypes of lymphomononuclear cells after peptide activation

\begin{tabular}{lcccc}
\hline Product tested & \multicolumn{4}{c}{ Cells expressing surface markers (\%) } \\
\cline { 2 - 5 } & CD11b & CD14 & CD16 & CD56 \\
\hline None & 6 & 5 & 5 & 4 \\
Pc & 6 & 5 & 6 & 5 \\
Pa & 18 & 16 & 16 & 20 \\
P1 & 15 & 13 & 12 & 13 \\
P2 & 15 & 17 & 20 & 15 \\
P3 & 16 & 17 & 20 & 19 \\
P4 & 10 & 13 & 14 & 14 \\
p5 & 17 & 16 & 17 & 16 \\
p6 & 15 & 15 & 16 & 20 \\
p8 & 10 & 12 & 14 & 16 \\
p10 & 16 & 16 & 16 & 17 \\
P11 & 19 & 17 & 19 & 19 \\
p13 & 12 & 15 & 16 & 14 \\
p14 & 10 & 12 & 15 & 16 \\
P16 & 14 & 16 & 17 & 13 \\
P17 & 14 & 15 & 20 & 17 \\
Fn & 10 & 11 & 13 & 13 \\
IL-2 & 5 & 4 & 11 & 22 \\
\hline Result & &
\end{tabular}

Results are representative of lymphomononuclear cells obtained from six different donors and processed independently and determined in duplicate after 7 days of incubation. Standard deviations were $<10 \%$. Peptides were used at a concentration of $30 \mu \mathrm{g} / 10^{6}$ cells, Fn at $40 \mu \mathrm{g} / 10^{6}$ cells and $\mathrm{IL}-2$ at $500 \mathrm{U} . / 10^{6} \mathrm{cells}$.

The elevation of CD14/CD16 induced by the active peptides may reflect a differentiation and maturation of monocytes. As strongly suggested by Ziegler-Heitbrock et al. [25], these $\mathrm{CD} 14^{+} / \mathrm{CD} 16^{+}$monocytes are more differentiated than $\mathrm{CD} 14^{++}$monocytes, are efficient as antigen presenting cells, have a higher tendency to migrate to the tissues, and may be consiclered as circulating macrophages.
The increase in CD11b (alpha chain of CR3), a marker related to phagocytosis [26], suggests that ECM proteins or peptides derived from them may also play a role in the activation of the phagocytic machinery.

The simultaneous expression of CD16 and CD56 or CD8 and CD56 surface markers has also been studied in lymphomononuclear cells incubated in the presence of some of the active peptides. The increase in the percentage of cells expressing CD56 (Table 3) could be specifically ascribed to NK or activated lymphocytes. NK (CD16/CD56) represent approx. 60\% and activated lymphocytes (CD8/CD56) $40 \%$ of the whole population of cells expressing CD56 surface markers (data not shown). These results suggest that peptides derived from ECM proteins induced not only a stimulation of monocytes, but also an activation of lymphocytes.

\subsection{Cytokine release}

In order to ascertain the possible stimulation of monocytes, cytokines IL- $1 \alpha$, IL- $1 \beta$ and TNF $\alpha$ were determined in the supernatants after the incubation of lymphomononuclear cells in the presence of peptides. The results collected in Table 4 clearly show that these cytokines were in fact released by the activated cells. LPS and active peptide $\mathrm{Pa}$ were used as positive controls. The nature of the TNF $\alpha$ released was confirmed with anti-TNF $\alpha$ antibody. It should be noticed that peptides P3 and P11 were also the most active as regards to the production of these cytokines. The concentration of IL- $1 \beta$ and TNF $\alpha$ in the supernatant was higher after $24 \mathrm{~h}$ than after $48 \mathrm{~h}$, whereas that of IL- $1 \alpha$ was slightly lower at $24 \mathrm{~h}$ than at $48 \mathrm{~h}$. It has been described that a $120 \mathrm{kDa}$ fragment of $\mathrm{Fn}$

Table 4

Cytokine release by lymphomononuclear cells after peptide activation

\begin{tabular}{|c|c|c|c|c|c|c|c|c|c|}
\hline \multirow[t]{2}{*}{ Product tested } & \multicolumn{3}{|c|}{ IL- $1 \alpha\left(\mathrm{pg} / 10^{6}\right.$ cells $)$} & \multicolumn{3}{|c|}{ IL-1 $\beta$ (ng $/ 10^{6}$ cells $)$} & \multicolumn{3}{|c|}{ TNF $\alpha\left(\mathrm{U} / 10^{6}\right.$ cells $)$} \\
\hline & $24 \mathrm{~h}$ & $48 \mathrm{~h}$ & $168 \mathrm{~h}$ & $24 \mathrm{~h}$ & $48 \mathrm{~h}$ & $\overline{168 \mathrm{~h}}$ & $\overline{24 h}$ & $48 \mathrm{~h}$ & $\overline{168 \mathrm{~h}}$ \\
\hline- & 20 & 25 & 7 & 1.1 & 1.3 & 0.5 & 50 & 50 & 15 \\
\hline Pc & 18 & 25 & 8 & 0.8 & 1.2 & 0.3 & 40 & 45 & 10 \\
\hline $\mathbf{P a}$ & 95 & 105 & 30 & 2.7 & 1.8 & 0.6 & 210 & 160 & 40 \\
\hline P1 & 76 & 84 & 60 & 1.7 & 1.4 & 0.4 & 180 & 160 & 30 \\
\hline $\mathbf{P} 2$ & 74 & 79 & 70 & 2.1 & 1.6 & 0.5 & 120 & 110 & 80 \\
\hline P3 & 100 & 120 & 45 & 2.7 & 2.1 & 0.4 & 280 & 180 & 60 \\
\hline P4 & 95 & 97 & 40 & 2.2 & 1.7 & 0.6 & 270 & 120 & 50 \\
\hline P5 & 65 & 80 & 50 & 1.7 & 1.4 & 0.6 & 220 & 110 & 60 \\
\hline P6 & 94 & 98 & 55 & 2.1 & 2.3 & 0.5 & 230 & 190 & 40 \\
\hline P8 & 63 & 78 & 30 & 1.8 & 1.9 & 0.5 & 210 & 170 & 30 \\
\hline P10 & 88 & 95 & 35 & 1.9 & 2.1 & 0.6 & 240 & 160 & 50 \\
\hline P11 & 85 & 100 & 35 & 2.8 & 2.5 & 0.5 & 240 & 180 & 40 \\
\hline P13 & 83 & 85 & 37 & 1.4 & 1.7 & 0.4 & 210 & 160 & 35 \\
\hline P14 & 65 & 80 & 35 & 1.9 & 2.2 & 0.5 & 190 & 150 & 45 \\
\hline P16 & 75 & 80 & 35 & 1.7 & 2.0 & 0.4 & 200 & 160 & 80 \\
\hline P17 & 65 & 82 & 15 & 2.2 & 2.4 & 0.3 & 220 & 170 & 50 \\
\hline Fn & 55 & 65 & 10 & 2.7 & 2.8 & 0.6 & 200 & 150 & 80 \\
\hline LPS & 180 & 185 & 150 & 3.5 & 3.0 & 1.2 & 380 & 330 & 170 \\
\hline
\end{tabular}

Results are representative of cells obtained from seven different donors and are the mean of the values obtained in two replicate wells. Standard deviations were $<10 \%$. Peptide concentration was always $30 \mu \mathrm{g} / 10^{6}$ cells. Fn, $40 \mu \mathrm{g} / 10^{6}$ cells; LPS, $10 \mu \mathrm{g} / 10^{6}$ cells. 
provokes a stimulation of monocytes accompanied by secretion of TNF $\alpha$ [4].

Cytokine release took also place when isolated monocytes were incubated for $24 \mathrm{~h}$ in the presence of $\mathrm{Pa}, \mathrm{P} 3$ or P11 (data not shown); the values were similar to those obtained with LPS, and more than double than those obtained with inactive control Pc.

IL-6 was determined in the supernatants of lymphomononuclear cells incubated in the presence of active peptides. In the presence of negative control Pc no significant release of IL-6 took place. Active peptides tested (Pa and P3) provoked a release of IL-6 (approx. $400 \mathrm{pg}$ per $10^{6}$ cells suspended in $\left.1 \mathrm{ml}\right)$ after $4 \mathrm{~h}$ of incubation. After $6 \mathrm{~h}$, values of up to $1200 \mathrm{pg}$ per $10^{6}$ were observed. Determinations carried out past $6 \mathrm{~h}$ and up to 10 days gave similar values.

\subsection{Increase in DNAse activity associated to secretion granules of activated lymphomononuclear cells}

Experiments were carried out in order to detect DNAse activity in the protein extracts from granules present in cells stimulated with some of the active peptides. The granules were obtained both from the entire incubated population of lymphomononuclear cells as well as from monocytes or lymphocytes isolated from it, after an incubation period of 7 days. The layer corresponding to the granules in the centrifugation gradient was clearly visible if the incubation had been carried out in the presence of active peptides, and almost imperceptible in the case of an

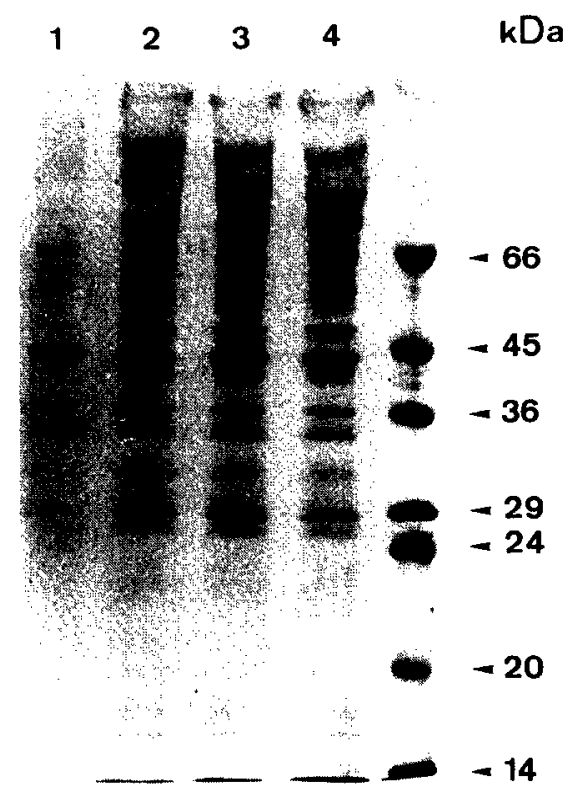

Fig. 2. SDS-PAGE of protein extracts from secretion granules obtained from lymphomononuclear cells incubated for 7 days in the presence of inactive peptide $\mathrm{Pc}$ (Lane 1), active peptide $\mathrm{Pa}$ (Lane 2), peptide $\mathrm{P} 3$, derived from fibronectin (Lane 3), and peptide P11, derived from $\alpha_{1}$ collagen IV (Lane 4).
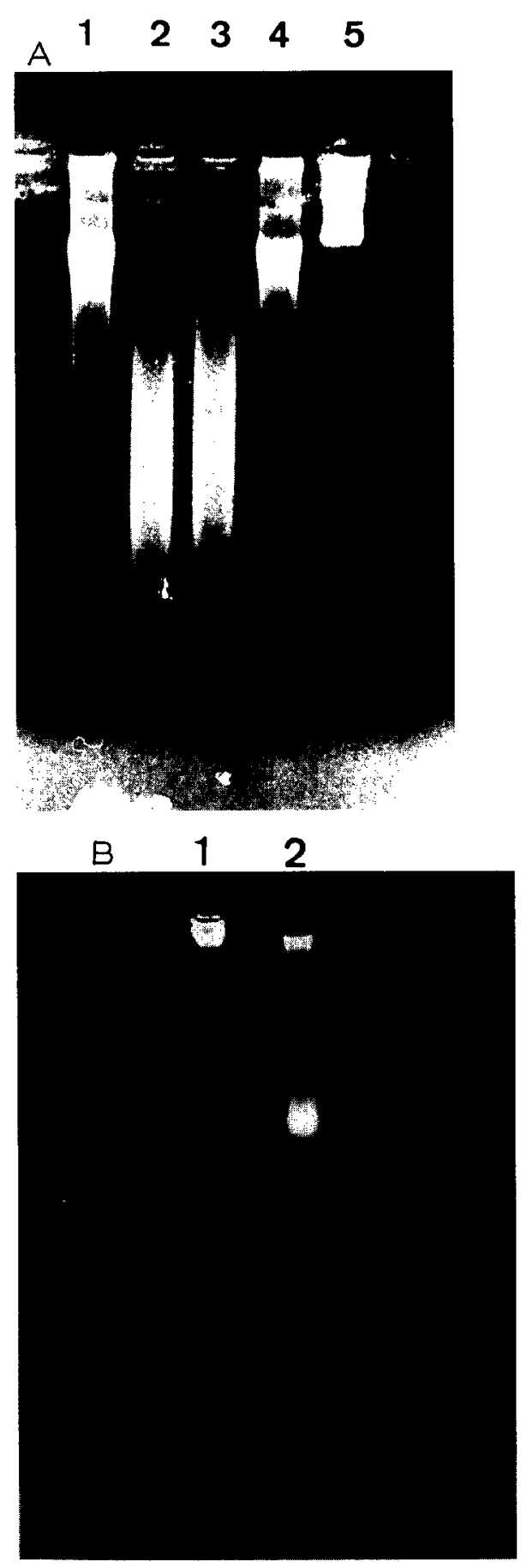

Fig. 3. Electrophoregram reflecting DNAse activity of protein extracts from secretion granules of lymphomononuclear cells incubated for 7 days under different conditions. Cells were carefully scraped off from culture flasks for further processing. (A) Activity present in monocytes isolated by means of magnetizable beads coated with CD14 antibody after incubation of lymphomononuclear cells in the absence of activators (lane 1), in the presence of control active peptide Pa (lane 2), peptide 3 (lane 3), control peptide Pc (lane 4). Protein-free human genomic DNA (lane 5). (B) DNAse activity present in granules obtained from cells remaining after the removal of monocytes. Cells had been previously incubated in the presence of inactive control Pc (lane 1), and P3 (lane 2) 
incubation with control peptide Pc, when using an equal number of cells. This is a clear indication that granule formation is part of the activation process. Fig. 2 shows a representative polyacrylamide gel electrophoregram of protein extracts from secretion granules belonging to an equal number of lymphomononuclear cells $\left(10^{8}\right.$ cells) incubated with Pc, Pa, P3 or P11 for 7 days. The electrophoregram reflects the increase in granule proteins after incubation in the presence of active peptides, with no apparent relative increase in any of the observed bands. The most prominent band in all the lanes corresponded to a $45 \mathrm{kDa}$ component.

A total of $10^{8}$ lymphomononuclear cells $\left(2 \cdot 10^{6}\right.$ cells per $\mathrm{ml}$ ) were incubated in the presence or absence of active peptides $\mathrm{Pa}, \mathrm{P3}, \mathrm{P} 11$, fibronectin or the inactive control peptide Pc; after the incubation the cells which had adhered were scraped off and resuspended in the medium; monocytes were then isolated by means of CD14-antibody coated magnetizable beads. Nuclease activity was assayed by electrophoresis on an agarose gel after incubation of genomic DNA together with the extracted granule proteins for $24 \mathrm{~h}$. Hydrolytic activity was detected in the extracts from granules obtained from the whole lymphomononuclear population incubated in the presence of $F n$ or the active peptides $\mathrm{Pa}, \mathrm{P} 3$ and $\mathrm{P} 11$ as well as from monocytes isolated after the incubation of lymphomononuclear cells. The electrophoregram of Fig. 3A clearly shows the fragmentation of genomic DNA caused by the protein extract corresponding to granules belonging to monocytes isolated from lymphomononuclear cells incubated in the presence of Pa or P3 (lanes 2 and 3). The granules obtained from monocytes isolated from an equal number of lymphomononuclear cells incubated in the absence of active peptides or in the presence of the negative control Pc exhibited no or very limited DNAse activity (lanes 1 and 4). Fig. 3A shows also that spontancous hydrolysis of DNA could be disregarded, since genomic DNA not exposed to cell extracts was left completely unaffected (lane 5). Fig. 3B shows that DNAse activity was also present in granules extracted from cells remaining after the removal of monocytes from the whole lymphomononuclear population incubated in the presence of P3 (lane 2), but not if they had been incubated in the presence of Pc (lane 1). Differences in digestion pattern between monocyte and non-monocyte granules could be due to different nucleases. The DNAse activity now reported could be associated to the $45 \mathrm{kDa}$ component; this possibility is suggested after the description by others of the existence of cytotoxic components with nuclease activity and similar molecular mass produced by macrophages activated with lipopolysaccharide or ionophore A23187 [27] and by cytotoxic T lymphocytes [28].

In conclusion, we have found that effects induced by Fn on the immune system, such as an enhancement of tumoricidal activity [22], or the secretion of TNF $\alpha$ by human monocytes ascribed to a large fragment of Fn [4], can also be obtained with small synthetic peptides containing se- quences present in fibronectin or other ECM proteins and fulfilling a well defined structural pattern. Furthermore, these active peptides have other effects, such as an increase in NK and LAK activity as well as a differentiation and activation of monocytes, not previously described for ECM proteins or peptides derived from them. In view of the potential of these peptides to stimulate the immune system it could be suggested that: (i) proteolytic fragments derived from circulating Fn may play a key role in the differentiation and activation of blood monocytes and lymphocytes; thus the proteolytic and autoproteolytic properties of Fn [29-32] could link this protein to the modulation of the immune system. In this respect it is interesting to note that fibronectin has several functional domains joined by flexible peptide segments highly sensitive to proteinases [33]; and furthermore, that the five sequences present in fibronectin with the '2-6-11' motif associated with immnunomodulation are contained within regions of the molecule marked by areas sensitive to proteinases [6].(ii) Peptides derived by in situ proteolysis of ECM proteins may be critical in the differentiation or activation of tissue macrophages and infiltrating lymphocytes under conditions such as an infection or the development of a tumour, in which proteolytic processes seem to increase.

\section{Acknowledgements}

This research was supported by a grant from Fundación Echebano.

\section{References}

[1] Lévesque, J.P., Hatzfeld, A. and Hatzfeld, J. (1991) Immunol. Today $12,258-262$.

[2] De Sousa, M., Tilney, N.L. and Kupiec-Weglinski, J.W. (1991) Immunol. Today 12, 262-266.

[3] Savino, W., Villa-Verde, D.M.S. and Lannes-Vieira, J. (1993) Inmunol. Today 14, 158-160.

[4] Beezhold, D.H. and Personius, C. (1992) J. Leukoc. Biol. 51, 59-64.

[5] López Moratalla, N., López-Zabalza, M.J., Subirá M.L., Borrás Cuesta, F., Pérez-Mediavilla, A. and Santiago, E. (1994) Biochim. Biophys. Acta 1221, 153-158.

[6] Skorstengaard, K., Jensen, M.S., Sahl, P., Petersen, T.E. and Magnusson, S. (1986) Eur. J. Biochem. 161, 447-453.

[7] Sasaki, M., Kleinman, H.K., Hubert, H., Deutzmann, R. and Yamada, Y. (1988) J. Biol. Chem. 208, 16536-16544.

[8] Pikkarainen, T., Eddy, R., Fukushima, Y., Byers, M., Shows, T., Pihlajaniemi, T., Saraste M. and Tryggvason, K. (1987)J. Biol. Chem. 262, 10454-10462.

[9] Soininen, R., Haka-Risku, T., Prockop, D.J. and Tryggvason, K. (1987) FEBS Lett. 225, 188-194.

[10] Gulcher, J.R., Nies, D.E., Marton, L.S. and Stefansson, K.(1986) Proc. Natl. Acad. Sci. USA 86, 1588-1592.

[11] Just, M., Herbst, H., Hummel, M. Dürkop, H. Tripier, D. Stein, H. and Schuppan, D. (1991) J. Biol. Chem. 266, 17326-17332.

[12] Yamaguchi, N., Benya, P.D., Van der Rest, M. and Ninomiya, Y. (1989) J. Biol. Chem. 264, 16022-16029. 
[13] Murugaki, Y., Jacenko, O., Apte, S., Mattei, M.G., Ninomiya, Y. and Olsen, B.R. (1990) J. Biol. Chem. 266, 7721-7727.

[14] Merrifield, R.B. (1963) J. Am. Chem. Soc. 85, 2149-2155.

[15] Atherton, E., Logan, J.C. and Sheppard, C.R. (1981)5 J. Chem. Soc. Perkin Trans. 1, 538-546.

[16] Nair, M.P.N., Kronfol, Z.A. and Schwartz, S.A. (1990) Clin. Immunol. Immunopathol. 54, 395-409.

[17] Meltzer, M.S. (1981) in Manual of Macrophage Methodology (Herscowitz, H.B. Holden, H.T., Bellanti, J.A. and Ghaffer, A., eds.), pp. 329-336, Marcel Dekker, New York.

[18] Podack, E.R. and Konigsberg, P.J. (1984) J. Exp. Med. 160, 695710.

[19] Podack, E.R., Young, J.D. and Cohn, Z.A. (1985) Proc. Natl. Acad. Sci. USA 82, 8629-8633.

[20] Laemmli, U.K. and Favre, M. (1973) J. Mol. Biol. 80, 575-579.

[21] Gross-Bellard, M., Oudet, P. and Chambon, P. (1973) Eur. J. Biochem. 36, 32-38.

[22] Perry, R.T., Kay, N.E., McCarthy, J., Vessella, R.L., Jacob, H.S. and Furcht, L.T. (1982) Blood 60, 430-436.

[23] Ziegler-Heitbrock, H.W.L., Strobel, M., Keiper, D., Fingerle, G., Schlunck, T., Petersmann, I., Ellwart, J., Blumenstein, M. and Haas, J.G. (1992) Blood 79, 503-511.

[24] Rutherford, M.S., Witsell, A. and Schook, L.B. (1993) J. Leukoc. Biol. 53, 602-618.
[25] Ziegler-Heitbrock, H.W.L.,Fingerle, G., Strobel, M., Schraut, W., Stelter, F., Schütt, C., Passlick, B. and Pforte, A. (1993) Eur. J. Immunol. 23, 2053-2058.

[26] Wright, S.D. and Silverstein, S.C. (1983) J. Exp. Med. 158, 20162023.

[27] Drysdale, B.E., Zacharchuk, C. and Shin, H. (1983) J. Immunol. 131, 2362-2367.

[28] Liu, C.C., Steffen, M., King, F. and Young, J.D. (1987) Cell 51, 393-403.

[29] Planchenault, T., Lambert Vidmar, S., Imhoff, J.M., Blondeau, X., Emod, I., Lottspeich, F. and Keil-Dlouha, V. (1990) Biol. Chem. Hoppe-Seyler 371, 117-128.

[30] Emod, I., Lafaye, P., Planchenault, T., I ambert Vidmar, S., Imhnff, J.M. and Keil-Dlouha, V. (1990) Biol. Chem. Hoppe-Seyler 371, $129-135$.

[31] Lambert Vidmar, S., Lottspeich, F., Emod, I., Planchenault, T. and Keil-Dlouha, V. (1991) Eur. J. Biochem. 201, 71-77.

[32] Lambert Vidmar, S., Lottspeich, F., Emod, I., Imhoff, J.M. and Keil-Dlouha, V. (1991) Eur. J. Biochem. 201, 79-84.

[33] Hayashi, M and Yamada,K.M., (1983) J.Biol. Chem. 258, 33323340. 